\title{
Şişkolar ve Sıskalar: Nasıl Olur? Biz Farklıyız! \\ Farklılıkların Ardından Doğan Bağa Vurgu Yapan Bir Çocuk Romanı
}

\author{
Merve Erol \\ Lisans Öğrencisi, Akdeniz Üniversitesi, Sosyoloji \\ Adres: Sosyoloji Bölümü, Akdeniz Üniversitesi, Antalya, Türkiye \\ E-Posta: merve1641@hotmail.com
}

Geliş Tarihi: 18 Haziran 2019 ; Kabul Tarihi: 6 Ağustos 2019

Doi: 10.24876/senex.2019.25

Künye: Erol, M., (2019). Şişkolar ve Sıskalar: Nasıl Olur? Biz Farklıyız! Farklılıkların Ardından Doğan Bağa Vurgu Yapan Bir

Çocuk Romanı. André Maurois İstanbul, 2018, Can Çocuk Yayınları, 77 s. Senex: Yaşlılık Çalışmaları Dergisi, 3, s. 70-72.

https://orcid.org/0000-0003-3588-4435

Özgün Adı: Patapoufs et Filifers

Yazar: André Maurois

Resimleyen: Fritz Wegner

Türkçeleştiren: Ülkü Tamer

Yayınevi: Can Çocuk Yayınları

19. Basım

ISBN: 978-975-510-060-9
Original Title: Patapoufs et Filifers

Author: André Maurois

Illustration: Fritz Wegner

Translation: Ülkü Tamer

Publisher: Can Çocuk Yayınları

19th Edition

ISBN: 978-975-510-060-9
"Çocuk edebiyatının önemli eserlerinden biri olan Şişkolarla Sıskalar adlı roman Türkiye'de ilk kez 1982 yılında yayın hayatına giren bir Fransız klasiği olarak karşımıza çıkmaktadır. Yazarı André Maurois ilk eserini 1918 yılında (Les silences du Colonel Bramble) dünya edebiyatına kazandırmıştır. Yazar öyküleri, romanları, tarih denemeleri, eleştiri yazılarıyla yirminci yüzyıl Fransız yazarlarının önemli isimleri arasında yer almaktadır.

Türkiye'deki ilk baskısı Can Çocuk Yayınları tarafından gerçekleştirilen kitap, yayınevinin çocuğa verdiği değeri göstermektedir.
1981 yılından günümüze dek Türk ve Dünya edebiyatından birçok seçkin eser Can Yayınevi aracılığıyla okurlarla buluşmuştur.

Şişkolarla Sıskalar ilk olarak ismi ve kapak resmiyle dikkat çeken bir roman. Kapak resmine baktığımızda kilolu bir kadın ve zayıf bir erkeğin yan yana mutlu bir fotoğrafını görmekteyiz. Bireylerin fiziksel farklılıklarını ötekileştirdiğimiz gündelik yaşantımızda kitabın adı ve kapağındaki görsel dikkat çekici bir unsur olmakla birlikte aynı zamanda uyandırdığı merak duygusu da sizi kitaba sürükleyebiliyor.

Kitap on iki bölümden oluşmaktadır. İlk olarak "Mutlu Bir Aile" ile başlayan bölümde roman 
karakterlerinin tanıtıldığın görmekteyiz.Ardından "Kemikistan Gemisi" "Göbekistan Gemisi" "Prens Şişgöbek" "Zayıflama Bakanı" gibi diğer bölümler birbirini izlemektedir. Her bölümü farklı ve

özgün isimler ile taçlandıran yazar okurun merak duygusunu canlı tutmaktadır. Kitabın içindeki akışta ise görselleştirmelere sıkça yer verilmiştir. Bu görselleştirmeler okuyucunun romanı hayal etmesini ve düşünmesini daha derinleştirmektedir.

Ünal ve İlkay birbirinden fiziksel olarak farklı iki kardeştir. İlkay Ünal'a göre daha zayıftır ve Illkay kardeşinin kilosu ile sürekli alay etmektedir. Bir gün oyun oynarken tırmandıkları tepenin ardında bambaşka bir dünyanın varlığını keşfederler. Bu dünya kendi yaşadıkları dünyadan farklı, yeraltında kurulmuş sadece iki ülkenin olduğu keşfedilmemiş bir yerdir. İki kardeş yeraltına geldiğinde görevliler İlkay'ı Kemikistan ülkesine Ünal'ı ise Göbekistan ülkesine göndermiştir. Göbekistan ve Kemikistan ülkesinin halkları birbirinden bağımsız iki halktır; halkların yaşam şekilleri de oldukça farklılık göstermektedir. Göbekistan'da yaşayan insanlar aşırı kilolu, yemeyi seven, rahatlıklarına önem veren insanlar olurken; Kemikistan halkı ise sadece yaşamak için yemek yiyen, zamanın büyük çoğunluğunu çalışmaya ayırdıkları bir yaşamsal düzene sahiptir; zaman onlar için öyle önemlidir ki yemeklerini bile ayakta hızlıca yiyip bitirirler.

Kitabın ilerleyen bölümlerinde iki kardeş ülkeler arasında çıkan anlaşmazlıklara son vermeye çalışırlar. Ülkelerin paylaşamadığı bir ada bulunmaktadır ve ülkeler adanın ismine karar verme aşamasında problemler yaşamaktadır. Bu problem iki ülke arasındaki savaşı başlatmıştır. Savaşın sonunda ise Göbekistan Krallığı ve paylaşılamayan ada Sıskaların eline geçmiştir ardından ortak bir ülke kurmaya karar vermişlerdir: Yeraltı Birleşik Devletleri. Sıskalarla Şişkolar böylelikle birarada yaşayabilecektir. Birbirlerinin alışkanlıklarını ve yaşam tarzlarını eleştiren iki halk savaşın ardından birbirlerine alışma sürecine girmiştir; zayıflar kilo almaya, kilolular ise zayıflamaya başlamıştır.

Etkileşim kavramına yapılan vurgu kitabın bu noktasında önem kazanmaktadır. İki ülke arasında evlilikler başlamıştır. Şişkolar ve Sıskalar için fiziksel farklılıklar artık problem değildir. Yaşamsal olarak da alışkanlıklar noktasında karşılıklı kültürel paylaşımda bulunabilecekleri bir ülke kurmuşlardır.

Kitabın son bölümünde "Şişkolarla sıskalar birleşmelidir. İnsanların kilolarına göre ayrıldıkları nerede görülmüş? Gerçeğin gerçek sayılabilmesi için elli kilodan az mı gelmesi gerekir? Şişkolar insan değil midir?" (Maurois, 2016:67). 'insan' olmanın niteliklerine vurgu yapıldığını görmekteyiz. Yazarın romanda yapmış olduğu vurguların en başında görünene yüklediğimiz yargılar ve anlamlar gelmektedir. Roman aslında fiziksel farklılıkların önemli olmadığını, her bireyin kendine öz belirli farklılıklarla yaşadığını, bireylerin bu farklılıkları anlamlandırmaya çalışmaları gerektiğini öğretileyen bir yapı içermektedir. Her toplum farklı kimlikleri ve kültürleri bünyesinde barındırır ancak toplumdaki bireylerin birbirleri ile etkileşim halinde olup olmadığı önemli bir noktayı oluşturmaktadır. Örneğin 'genç' ve 'yaşlı' kimliklerine yüklenen anlamlar, belirli davranış kalıpları ve roller mekansal ayrışmaya sebep olmaktadır. Bu durumun genç ve yaşlı bireyi toplumsal yaşamda fiziksel ve sosyal etkileşim noktasında birbirinden uzaklaştırdığını söylemek mümkündür. Kuşaklararası zıtlaşmayı doğuran bu durum genç ve yaşlı bireylerin sosyal 
karşılaşmalarının ve etkileşimlerinin önüne geçmektedir. Almanya'da kuşaklararası karşılaşmaya ve kuşaklararası iletişime destek veren bir proje gerçekleştirilmiştir: "Aktif Park Projesi". Bu projede kamusal alana yapılan vurguya dikkat çekilmekle birlikte kamusal alanın gence, yaşlıya, çocuğa ait olduğu vurgusu yapılmaktadır. Kentli bireylerin fiziksel ve sosyal etkileşimlerini arttırmaya yönelik hareketliliği amaçladıkları bir çalışmadır. Genç, yaşlı, engelli veya engelsiz tüm bireylerin bir karşılaşma mekanı olarak tasarlanan bu proje kent yaşamının sessizliğini ıran bir projedir. Ülkemizdeki spor parklarının da aynı amaç doğrultusunda etkileşimi sağladığı söylenebilir. Çocukların farklı kimliklere olan bakış açılarını olumlu bir algı ile beslemeyi aynı zamanda benlik oluşumu sürecinde kendilerinin de bir gün yaşlı kimliğine ulaşacaklarını kabullenmeleri noktasında kuşaklarası etkileşimin çocukların gelişimi açısından önemli olduğunu söyleyebiliriz. Yaşlı bireyin de sosyal ve fiziksel olarak aktif olması kendini öteki olarak değerlendirmemesi noktasında önemlidir.
Kuşaklararası dayanışma ve bu dayanışmanın topluma yayılması bireylerin kent yaşamının yalnızlığını ve bireyselliğini aşma noktasında da önem kazanmaktadır. Sonuç olarak kitabın asıl yazılma amacı savaş dönemine yapılan vurgu olurken yazar gündelik yaşantımızda oluşturduğumuz farklı gruplarla ve kimliklerle olan savaşlara son vermemiz gerektiğini iki ülkenin savaşı ile tasvir etmiştir. Fiziksel ve kültürel anlamda romanda biçim kazanan iki ülkenin halkı; çocuk, genç ve yaşı kimliklerini aynı zamanda toplumda ötekileştirilen diğer kimlikleri de bize hatırlatmaktadır. Öteki bireyi tanımak ve etkileşim halinde olma duygusu önem kazanırken farklılıkların kaçınılmaz olduğu unutulmamalıdır. İnsanı anlamak ve farklı olanı kendi içinde kabullenmek kitabın okuyucuya sunduğu en önemli öğretidir.

\section{Kaynakça}

Maurois, A., (2016). Şişkolar ve Sıskalar. (Çev. Ü. Tamer). İstanbul: Can Çocuk Yayınları. 